Shchepotina, N., Kostiukevych, V., Asauliuk, I., Stasiuk, V., Vozniuk, T., Dmytrenko, S., \& Adamchuk, V. (2021). Management of Training Process of Team Sports Athletes During the Competition Period on the Basis of Programming (Football-Based). Teoria ta Metodika Fizičnogo Vihovannâ, 21(2), 142-151. https://doi.org/10.17309/tmfv.2021.2.07

ISSN 1993-7989 (print). ISSN 1993-7997 (online)

\title{
MANAGEMENT OF TRAINING PROCESS OF TEAM SPORTS ATHLETES DURING THE COMPETITION PERIOD ON THE BASIS OF PROGRAMMING (FOOTBALL-BASED)
}

\author{
Natalia Shchepotina ${ }^{1 \mathrm{ABCDE}}$, Viktor Kostiukevych ${ }^{\mathrm{ABCDE}}$, Inna Asauliuk ${ }^{1 \mathrm{BCDE}}$, Vadym \\ Stasiuk $^{2 \mathrm{BCDE}}$, Tetiana Vozniuk ${ }^{1 \mathrm{BCDE}}$, Svitlana Dmytrenko ${ }^{1 \mathrm{BCDE}}$, Vadym Adamchuk ${ }^{1 \mathrm{BCDE}}$ \\ ${ }^{1}$ Vinnytsia Mykhailo Kotsiubynskyi State Pedagogical University \\ ${ }^{2}$ Kamianets-Podilskyi Ivan Ohiienko National University \\ Authors' Contribution: A - Study design; B - Data collection; C - Statistical analysis; D - Manuscript Preparation; E - Funds Collection
}

Corresponding Author: Viktor Kostiukevych, E-mail: kostykevich.vik@gmail.com

Accepted for Publication: May 18, 2021

Published: June 25, 2021

DOI: 10.17309/tmfv.2021.2.07

\begin{abstract}
The purpose of the study was to experimentally substantiate the effectiveness of organization of structural arrangements of the training process in skilled football players within the limits of the competition period on the basis of programming.

Material and methodology. 18 skilled football players of "Burevisnyk" student team took part in the research. The average age of participants was $19.8 \pm 5.8$ years and the qualification was category 1 . The programme of the competition period of the skilled football players consisted of four blocks: the first one included the types and ratios of the training work, the second one included quantitative indexes of training sessions (non-specific, specific, comprehensive) and games (educational, control, official), and the third one included the ratio of means (general preparatory exercises, special preparatory exercises, developing exercises, competitive exercises) and training loads (aerobic, mixed aerobic and anaerobic, anaerobic alactic, anaerobic glycolytic loads), and the fourth one included preparedness criteria.

Results. We have redistributed training loads of various orientation by taking into account the specifics of competitive loads in skilled football players. Thus, shares of loads of the aerobic and anaerobic glycolytic orientation at the formative stage of the experiment were increased by 53.6 and $3.0 \%$, respectively, and the loads of the mixed and anaerobic alactic orientation were decreased by 40.0 and $3.4 \%$, respectively. Positive dynamics of indexes of physical (1.2-2.2\%) and functional (5.4-6.7 \%) preparedness and competitive activity (3.6-23.8 \%) of skilled football players at the formative phase of the experiment in comparison to the ascertaining phase was evident.

Conclusions. Theoretical and methodical aspects of programming of the training process may be conditioned upon the hierarchical structure, in which smaller programmatic structural arrangements are subordinate to the larger ones; the objectives with respect to the training programmes at every phase of the training macrocycle; general and special principles of athlete training; algorithmicity, i.e. step-by-step planning and correction of managerial influences; proper selection of training means and use of training loads with different focuses in the process of training cycles; use of informational criteria for control at every phase of the training process.

Keywords: football players, competitive period, program, managerial influences, microcycles, load orientation, load volume, physical preparedness, functional preparedness, competitive activity.
\end{abstract}

\section{Introduction}

Preparatory, competitive and transitional periods of the macrocycle are successive stages of the process of managing the development of sports form. Maintaining sports form in players during the long-lasting competition period for team sports is one of the central problems in the system of athlete

(C) Shchepotina, N., Kostiukevych, V., Asauliuk, I., Stasiuk, V., Vozniuk, T., Dmytrenko, S., Adamchuk, V., 2021. training (Kostiukevych, Lazarenko, Shchepotina, Kulchytska et al., 2019). Objective regularities of organism development do not allow for an increase in the training load. Due to this fact, experts continue to hold discussions on the optimum parameters of physical loads in athletes during the competition period. And specifically, works by Andrade et al. (2018) and Duarte et al. (2019) studied the peculiarities of training loads and recovery in volleyball players during the competition period. Assessment of external and internal side of the 
training load in elite football players during the competitive period was presented in the studies by Oliveira et al. (2019). The purpose of studies by Manzi et al. (2010) was to determine main parameters of physical loads in elite basketball players during various regimens of weekly microcycles, depending on the calendar of competitions.

Thus, taking into account modern tendencies of the development of team sports, among which the expansion of competition calendar and the increase in the competition practice should be given first priority, while the need for optimization of the training process in players during the competition period becomes evident (Andrade et al., 2018; Kostiukevych, Lazarenko, Shchepotina, Poseletska et al., 2019). It becomes possible due to rational planning of stimulation and recovery phases, i.e. regimens of load and rest for the purpose of forming urgent, delayed and cumulative training effects (Bompa \& Haff, 2009; Platonov, 2013; Koryahin, Blavt, Doroshenko et al., 2020). However, on the basis of traditional planning which determines only the distribution of quantitative parameters of training work in structural arrangements of a macrocycle it is difficult to consider the training process of athletes in dynamics in conjunction with different sides of training (Kostiukevich, Stasiuk, Shchepotina et al., 2017). And most importantly, planning does not allow to determine direct impact on the formation of training effects. For this purpose, programming of training process may be used in the structure of managerial influences (Gerhard, 2009; Khudolii, 2019; Adamchuk, 2020).

Theoretical and methodical foundations of programming in the system of training in team sports athletes were substantiated by a wide circle of specialists, however, primarily with respect to separate components of training. And specifically, multidirectional programmes of physical training in female volleyball players were presented in the works by Malikova et al. (2018) and Veličković et al. (2018). As for football players' training, Karsten et al. (2016) proposed to use programming method in the process of strength-focused training of players. Comprehensive programme for the development of physical qualities in football players was presented in the study by Chtara et al. (2017). A more substantive approach was proposed by Shamardin (2013): the author developed two variants of training of a football team which takes part only in the championship of Ukraine and of a team which takes part in the Eurocup.

Presented analysis of literary sources allows to claim that the problem of programming of training process in athletes is relevant and promising. At the same time, the accumulated data related to the peculiarities of programming of athlete training in the team sports requires further study and clarification. Therefore, substantiation of scientific and methodical approach to the development of programmes of structural arrangements of the training process in athletes of team sports within the limits of an annual macrocycle and the ways of its practical fulfilment remains opportune which encouraged our study.

Study hypothesis: it is foreseen that the programming of structural arrangements of the training process in skilled football players within the limits of the competition period allows to optimize training loads by way of targeted managerial influences.

The purpose of study was to experimentally substantiate the effectiveness of organization of structural arrangements of the training process in skilled football players within the limits of the competition period on the basis of programming.

\section{Material and methodology}

\section{Study participants}

18 skilled football players of "Burevisnyk" student team took part in the research. The average age of participants was $19.8 \pm 5.8$ years and the qualification was category 1 . The criteria for inclusion of football players into the sample was their game status: a starter player or an active backup player. The study was approved by the ethics committee of Vinnytsia Mykhailo Kotsiubynskyi State Pedagogical University and all the procedures were in accordance with the Helsinki Declaration. The participants gave an informed consent for participation in the experiment.

\section{Study organization}

The study was conducted over the period of two years. The ascertaining phase of the experiment was conducted over the first year and the formation phase was conducted over the second year. Pedagogical supervision of the training process of the studied football team was conducted during the ascertaining experiment. Real time monitoring of the training work which foresaw recording of the nature and duration of exercises and heart rate of players on special forms during the performance of exercises using heart rate monitor Polar RS800CX allowed to determine:

1) general volume of motor activities in athletes (minutes, hours);

2) load value coefficient (LVC) using the method of V.A. Sorvanov (Godik, 2006). LVC was calculated as a result of multiplication of the duration of the exercise by its intensity in points depending on the heart rate (Kostiukevich, Stasiuk, Shchepotina et al., 2017): intensity of exercise with the heart rate $114 \mathrm{bpm}$ was evaluated in 1 point; $120 \mathrm{bpm}$ 2 points; $126 \mathrm{bpm}-3$ points; $132 \mathrm{bpm}-4$ points; $138 \mathrm{bpm}-$ 5 points; $144 \mathrm{bpm}-6$ points; $150 \mathrm{bpm}-7$ points; $156 \mathrm{bpm}-$ 8 points; 162 bpm - 10 points; 168 bpm - 12 points; 174 bpm - 14 points; $180 \mathrm{bpm}-17$ points; $186 \mathrm{bpm}-21$ points; 192 bpm - 25 points; 198 bpm - 33 points;

3) load intensity using the coefficient of the training load intensity (CItl) was determined as a ratio of the LVC to the duration of the training session in minutes (CItl, point $\cdot \mathrm{min}^{-1}$ );

4) ratio of multidirectional means while taking into account the specifics of the team sports: general preparedness exercises, special preparedness exercises, developing and competitive exercises (Platonov, 2013; Kostiukevich, 2016);

5) ratio of physical loads with various physiological orientation: loads of aerobic, mixed aerobic-anaerobic, anaerobic alactate or anaerobic glycolytic orientation (Johnson, Haskvitz, \& Brehn, 2009; Wilmore, Costill, \& Kenney, 2012; Platonov, 2013).

Pedagogical testing allowed to determine the indexes of physical preparedness in players and foresaw the use of tests: $30 \mathrm{~m}$ run from high start (the best result out of two attempts was taken into account, with a rest interval of 3-5 minutes), $7 \times 50 \mathrm{~m}$ shuttle run (running seven fifty meter stretches with a mandatory condition that the support leg is put over the start and finish line), long jump from the spot (three attempts 
were made and the best result among them was recorded), Cooper test (continuous run during 12 minutes with determination of the distance which the player overcame; the test was preceded by 5 minute rest after warm-up). All the tests were conducted according to the generally accepted method after an obligatory warm-up, they correspond to the requirements of reliability and informativeness and are standard for assessment of physical preparedness in football players (Godik, 2006; Kostiukevich, Stasiuk, Shchepotina et al., 2017). Athletes were first given instructions on the correctness of the performance of test exercises. Pedagogical testing was organized over the period of two days: $30 \mathrm{~m}$ run and $7 \times 50 \mathrm{~m}$ shuttle run on the first day, long jump from the stop and Cooper test on the second day.

Maximum oxygen consumption $\left(\mathrm{VO}_{2 \max }\right)$ was determined by indirect method and was based on the high correlation between physical preparedness and aerobic productivity of an organism (Karpman, Belotserkovskiy, \& Gudkov, 1988). According to the method for conducting a run-based variant of the test $P W C_{170(\mathrm{~V})}$ (Kostiukevich, 2016) the players performed two 5-minute run loads by overcoming the distances of 700-900 and 1100-1300 m accordingly, with their heart rate being recorded at the end of the first and second load (the period of rest between run loads made 5 minutes). $P W C_{170(\mathrm{~V})}$ was determined using the formula:

$$
P W C_{170(V)}=V_{1}+\left(V_{2}-V_{1}\right) \frac{170-f_{1}}{f_{2}-f_{1}}
$$

whereas: $V_{1}$ and $V_{2}$ represent run speed during the first and second run loads (determined as a ratio between the distance length and the time for overcoming the distance), $\mathrm{m} \cdot \mathrm{s}^{-1}$; $f_{1}$ and $f_{2}$ represent heart rate immediately after the first and second run load, bpm.

The following formula (Karpman, Belotserkovskiy, \& Gudkov, 1988) was used to convert $P W C_{170(\mathrm{~V})}$ in $\mathrm{m} \cdot \mathrm{s}^{-1}$ into $P W C_{170}$ in $\mathrm{kgm} \cdot \mathrm{min}^{-1}$

$$
P W C_{170}=417 \cdot P W C_{170(\mathrm{~V})}-83 \text {, }
$$

Absolute index of maximum oxygen consumption $\left(\mathrm{VO}_{2 \max }, \mathrm{ml} \cdot \mathrm{min}^{-1}\right)$ was determined using the formula:

$$
\mathrm{VO}_{2 \max }=1,7 \cdot P W C_{170}+1240 \text {, }
$$

Relative index of maximum oxygen consumption $\left(\mathrm{VO}_{2 \max (\mathrm{rel})}, \mathrm{ml} \cdot \mathrm{min}^{-1} \cdot \mathrm{kg}^{-1}\right)$ was determined as a ratio of an absolute index to the body mass of the studied football player.

The results of completion of the $7 \times 50 \mathrm{~m}$ shuttle run by football players allowed to determine the overall index of adaptation by Nevmianov which characterized the level of adaptation of the player's organism to loads of anaerobic glycolytic orientation (Kostiukevych, 2016):

$$
O I A=t\left(f_{1}+f_{2}+f_{3}\right) \text {, }
$$

whereas: $t$ is the time of performance of $7 \times 50 \mathrm{~m}$ shuttle run test; $f_{1}, f_{2}, f_{3}$ is heart rate over 10 seconds at the end of the first, second and third minute of recovery.

The assessment of the competitive activity of football players was performed on the basis of 6 developed specific indexes (coefficients of intensity, mobility, aggressiveness, efficiency, single combat efficiency, creativity) as well as overall assessment, the method of determination of which is described in detail in our previous studies (Kostiukevych, Imas, Borysova et al., 2018; Kostiukevych, Shchepotina, \& Vozniuk, 2020).

1. The intensity coefficient (IC) determined the overall activity of the player in the game:

$$
I C=\frac{\sum_{i=1}^{n} T T A}{t}
$$

where: $\sum_{i=1}^{n} T T A$ - total amount of technical and tactical $t$ - time played by a player in a match.

2. The mobility coefficient (MC) characterized the general mobility of the player during the match, his desire to perform technical and tactical actions in motion in different parts of the field:

$$
M C=\frac{\sum_{i=1}^{n} T T A(2 n d M C C+3 r d M C C)}{t} \times 2
$$

where: $\sum_{i=1}^{n} T T A(2 n d M C C+3 r d M C C)$ - total amount of technical and tactical actions performed by the player in the second and third modes of coordination complexity;

2 - indicator of coordination complexity.

3. The aggressiveness coefficient (AC) characterized the player's activity in single combats, in conditions of active intervention by the opponent:

$$
A C=\frac{\sum_{i=1}^{n} T T A(3 r d M C C)}{t} \times 3
$$

where: $\sum^{n} T T A(3 r d M C C)$ - total amount of technical and tactical actions performed by the player in the third mode of coordination complexity;

3 - indicator of coordination complexity.

4. The efficiency coefficient (EC) reflected the value of the player for the team, the quality of performed by him technical and tactical actions:

$$
E C=\frac{\sum_{i=1}^{n} \text { preciseTTA }}{\sum_{i=1}^{n} \text { allTTA }}
$$

where: $\sum_{i=1}^{n}$ preciseTTA - total amount of precise technical and tactical actions performed by the player;

$\sum_{i=1}^{n}$ allTTA - total amount of all technical and tactical actions performed by the player in a match.

5. The single combat efficiency coefficient (SCEC) characterized the quality of technical and tactical actions performed by the player in conditions of active intervention by the opponent:

SCEC $=\frac{\sum_{i=1}^{n} \text { preciseTTA }(\text { stops }, \text { holds, tackings, dummies, performed in } 3 r d \text { MCC })}{\sum_{i=1}^{n} \text { allTTA }(\text { stops }, \text { holds, tacklings, dummies, performed in } 3 r d M C C)}$

where:

$\sum_{i=1}^{n}$ preciseTTA(stops, holds, tackings, dummies, performedin $\left.3 r d M C C\right)$ - total amount of precise technical and tactical actions performed by the player in the third mode of coordination complexity; $\sum_{i=1}^{n}$ allTTA(stops, holds, tackings, dummies, performedin $\left.3 r d M C C\right)$ - total amount of all technical and tactical actions performed by the player in the third mode of coordination complexity during the match.

6. The creativity coefficient (CC) allowed us to integrally evaluate the player's game creativity in the confrontation 
with the opponent. Usually a player with a high creativity coefficient must be confident in his actions, have a wide arsenal of technical and tactical actions and be able to apply them in accordance with the situation:

$$
C C=\frac{\sum_{i=1}^{n} \operatorname{preciseTTA}(D P \times 1+S P \times 2+G P \times 5+G K \times 5+G \times 10)}{t}
$$

where: $D P$ - developing passes; $S P$ - sharpening passes; $G P$ goal passes; $G K$ - goal kicks; $G$ - goals.

7. The integral assessment (IA) of player was determined by the sum of six specific indicators and was one of the criteria for creating an athlete rating :

$$
I A=I C+M C+A C+E C+S C E C+C C
$$

Results of the ascertaining experiment provided scientific and methodical basis for programming the training process in football players during the competition period. Programming of structural arrangements of the training process consisted in the progressive development of the interconnected programmes of periods, microcycles, training sessions and their parts (training tasks) which definitely included load components for targeted formation of urgent, delayed and cumulative training effects. Programmes of structural arrangements of the training process in football players were based on the regularities of the development of adaptation processes, general principles of athlete training, peculiarities of athlete training in team sports etc. (Matveev, 2010; Wilmore, Costill, \& Kenney, 2012; Platonov, 2013).

Programme of the competition period of the skilled football players consisted of four blocks (fig. 1): the first one included the types and ratios of the training work, the second one included quantitative indexes of training sessions (nonspecific, specific, comprehensive) and games (educational, control, official) and the third one included the ratio of means (general preparatory exercises, special preparatory exercises, developing exercises, competitive exercises) and training loads (aerobic, mixed aerobic and anaerobic, anaerobic alactate, anaerobic glycolytic loads) and the fourth one included preparedness criteria.

The fulfilment of the proposed programme of competitive period was carried out through the logical flowchart of the microcycles programme (fig. 2). Main target tasks for each microcycle were: formation of training effects, adaptation of players to training and competitive loads, improvement of technical and tactical skills.

Programmes for microcycles of various types, i.e. competitive, intergame, recovery microcycles, were developed for the competitive period. The structure of the microcycle proposed by Kostiukevich (2016) was taken as a basis. Load components were clearly regulated in each microcycle: volume, load value and intensity, training means etc.

The development of programmes of training sessions which solved the tasks of adaptation of football players to loads took into account such regularities and principles of formation of training effects as superloads and stress syndrome, dose/effect dependence, specificity, reversibility of the action, positive interaction, adaptation coherence (Bompa \& Haff, 2009; Matveev, 2010; Platonov, 2013). Taking these regularities into account, fig. 3 shows the dynamics of load, intensity and orientation of 6-day competitive microcycle of preparedness of the skilled football players.

\section{Statistical analysis}

Descriptive statistics was used during mathematical processing of study outcomes. The mean (M) and standard deviation (SD) were determined. In order to determine statistical reliability in the difference of indexes of preparedness

\begin{tabular}{|c|c|c|}
\hline Non-specific & Specific & Comprehensive \\
\hline 21 & 54 & 22 \\
\hline \multicolumn{2}{|c|}{ TRAINING SESSIONS } \\
\hline
\end{tabular}

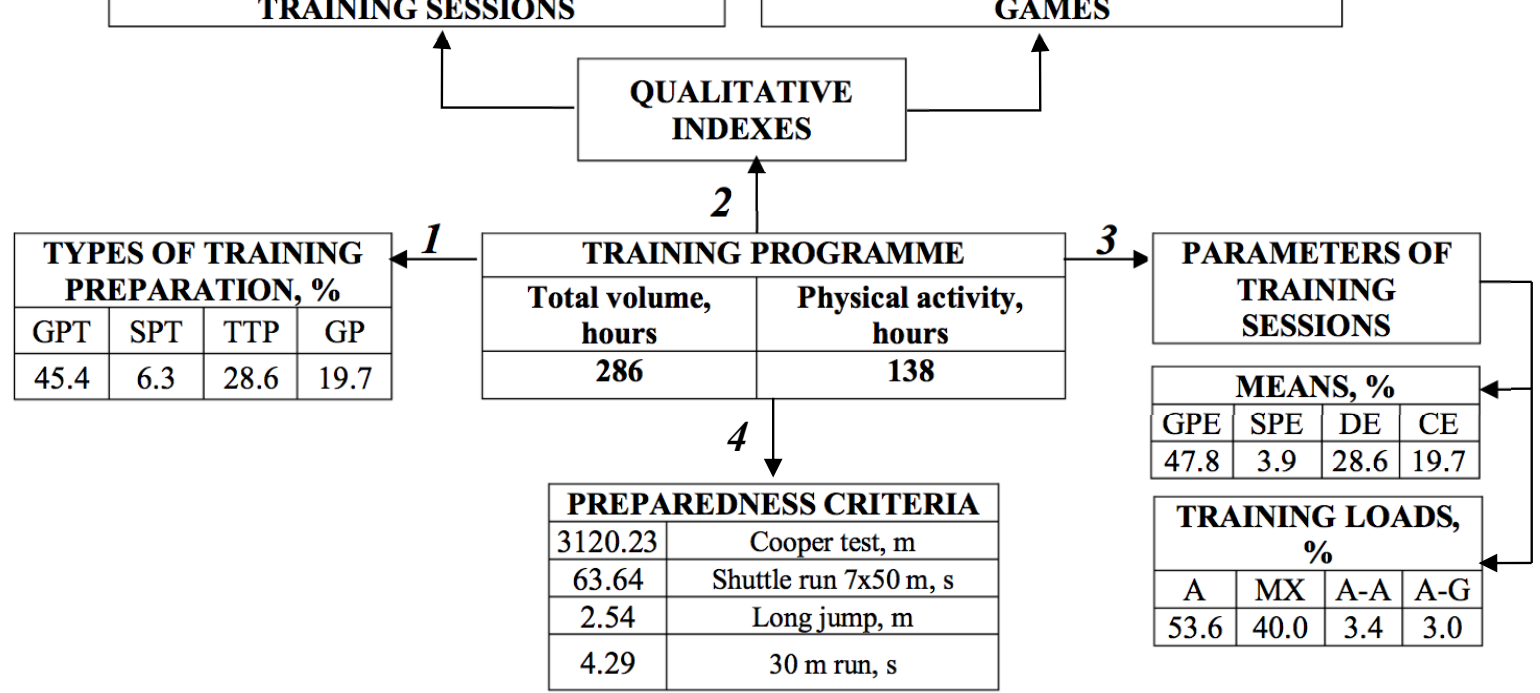

Fig. 1 The programme of preparedness of skilled football players during the competition period of the second cycle of annual preparation at the phase of the formation experiment: GPT - general physical training; SPT - special physical training, TTP - technical and tactical preparation, GP - game preparation; means: GPE - general preparatory exercises, SPE - special preparatory exercises, DE - developing exercises, $\mathrm{CE}$ - competitive exercises; training loads; A - aerobic, MX - mixed aerobic anaerobic, A-A - aerobic alactate, A-G - aerobic glycolytic 


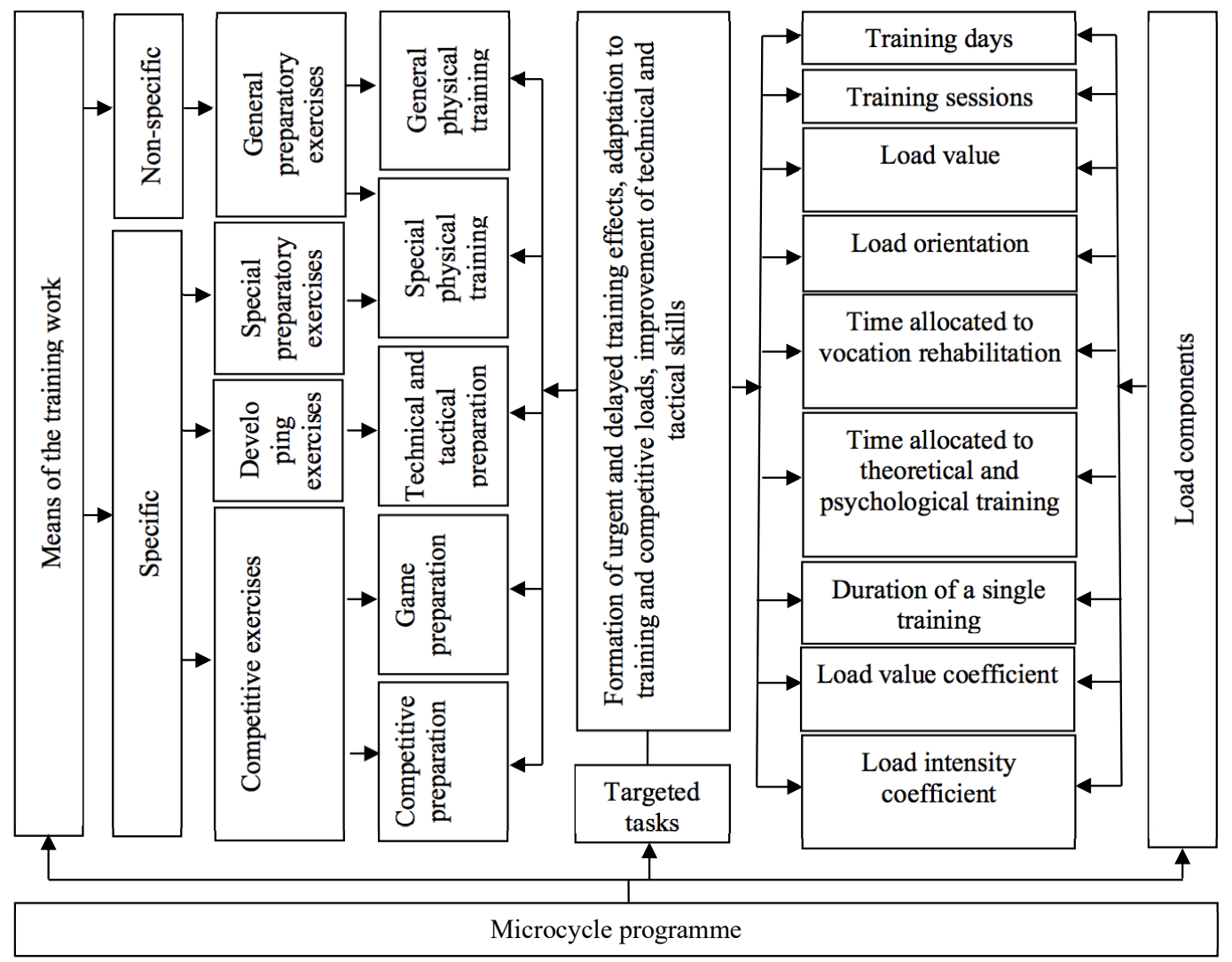

Fig. 2. Logical flowchart of microcycles in the training process of the skilled football players

Volume, min

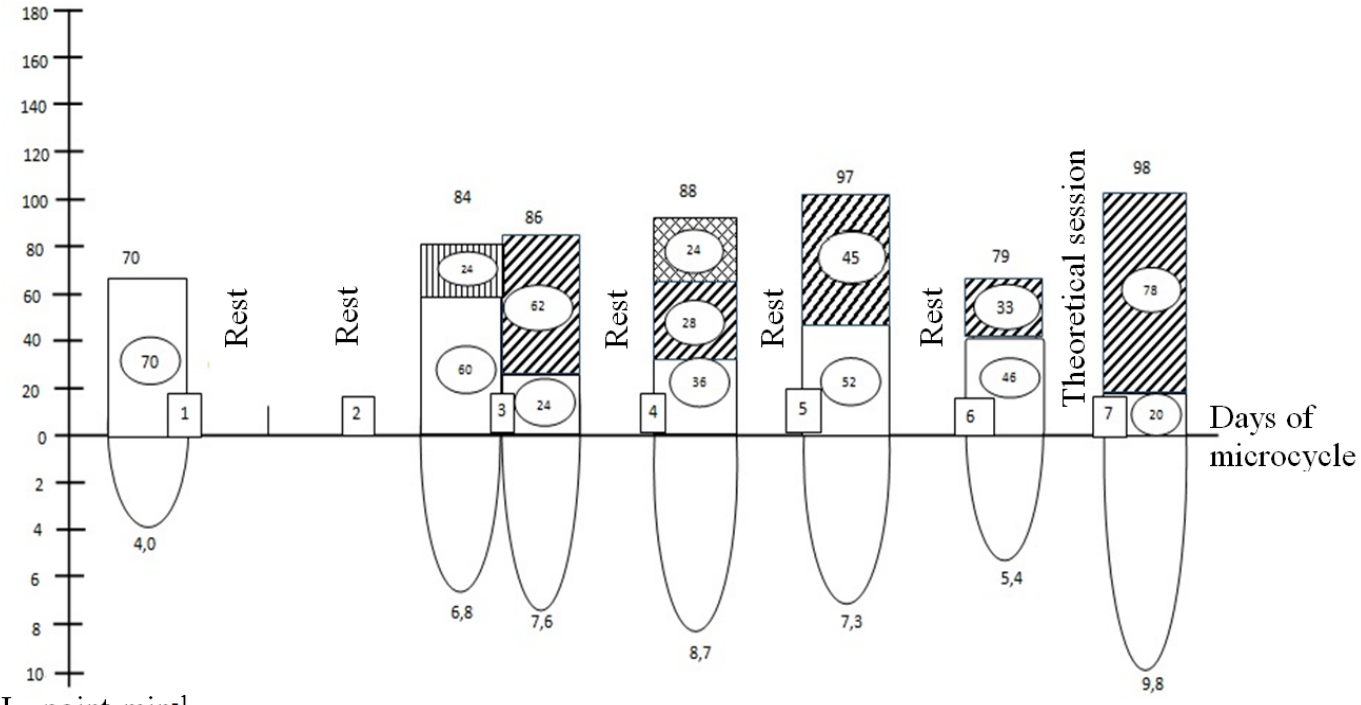

$\mathrm{CI}_{\mathrm{tl}}$, point $\cdot \mathrm{min}^{-1}$

Fig. 3. Volume, intensity (CItl) and orientation of sessions of 7-day competitive (recovery and developing) microcycle of the competitive period of the second cycle of annual training of the skilled football players at the phase of the formation experiment: $\square$ - loads of aerobic orientation; $\mathbf{Z}$ - loads of mixed orientation; $\mathbb{W}$ - loads of anaerobic alactate orientation; $\mathbb{\nabla}$ - loads of anaerobic glycolytic orientation

and competitive activity of football players at the ascertaining and formulation phases of the experiment, Student's t-criterion was used for dependent samples. The difference between indexes was considered reliable at the levels of significance $\mathrm{p}<0.05$ and $\mathrm{p}<0.01$. Mathematical processing of the results was conducted using the package "Data analysis" of MS Office Excel software (Byshevets, Shynkaruk, Stepanenko et al, 2019). 


\section{Results}

The content of the training process of the studied football team at the formation phase of the experiment was significantly changed. Besides, the volume of training loads was reduced from $9022 \mathrm{~min}$ (150,4 hours) at the ascertaining phase up to $8250 \mathrm{~min}$ (137,5 hours) at the formation phase. The structure of the competitive period included eight 7-day competitive (recovery and developing), two 6-day competitive (recovery and developing), one 5-day competitive (developing), three 4-day competitive (developing) and four 3-day recovery microcycles (table 1).

Besides, in comparison with the ascertaining phase of experiment we have redistributed training loads of various orientation by taking into account the specifics of competitive loads in skilled football players (fig. 4). Thus, shares of loads of aerobic and anaerobic glycolytic orientation at the formation stage of the experiment were increased by 53.6 and 3.0\% accordingly and the loads of the mixed and anaerobic alactate orientation were decreased by 40.0 i $3.4 \%$ accordingly.

Positive dynamics of indexes of physical and functional preparedness and competitive activity of skilled football players at the phase of the formation experiment in comparison to the ascertaining phase (table 2) was evident. Besides, the level of demonstration of speed endurance in football players reliably improved $(p=0.05)$ by $2.2 \%$ based on the index of $7 \times 50$ $\mathrm{m}$ shuttle run which significantly contributed to the increase in the share of loads of anaerobic glycolytic orientation. The rest of indexes of physical preparedness in players showed positive dynamics within the limits of 1.2-1.4 $\%(\mathrm{p}>0.05)$.

An increase in the share of loads of aerobic orientation showed itself in a statistically reliable improvement of functional indexes in football players which characterized the level of physical ability to work using the indexes $\mathrm{PWC}_{170(\mathrm{~V})}$ and $\mathrm{PWC}_{170}$ multiplied by $6.7 \%(\mathrm{p}=0.00)$ and $6.9 \%(\mathrm{p}=0.05)$ accordingly and aerobic productivity using the relative index of $\mathrm{VO}_{2 \max (\mathrm{rel})}$ multiplied by $5.8 \%(\mathrm{p}=0.04)$.

Regulation of load components, quantitative indexes of training sessions and games, ratio of means for training football players which became possible due to the use of programming allowed to perform targeted managerial influences, to optimise the training process and contributed to the reliable improvement of majority of specific indexes and overall assessment of competitive activity in football players. Thus, the intensity coefficient at the phase of the formation experi-

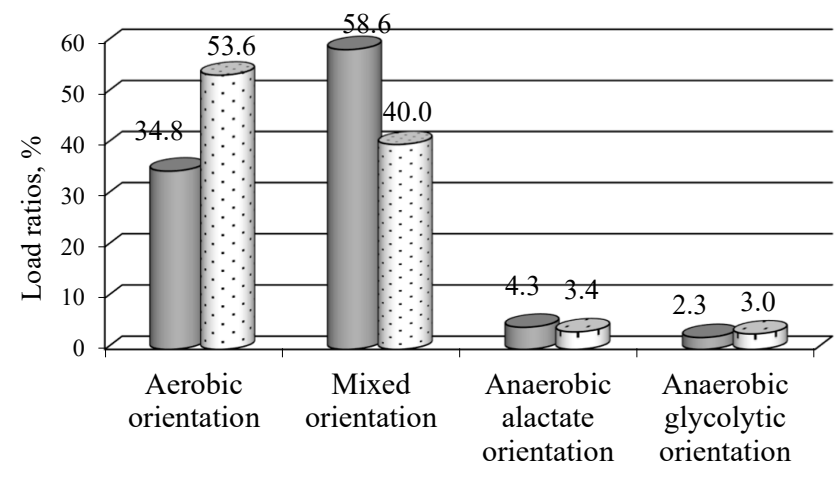

Fig. 4 The ratio of training loads of various orientation during the competition period in skilled football players at the ascertaining and formation phases of the pedagogical experiment is the following: - ascertaining phase; - formation phase

ment, in comparison with the ascertaining phase, increased by $14.1 \%(\mathrm{p}=0.01)$, the mobility coefficient increased by $14.4 \%(\mathrm{p}=0.00)$, the efficiency coefficient increased by $11.6 \%$ $(p=0.00)$ and the creativity coefficient increased by $23.8 \%$ $(\mathrm{p}=0.01)$. An increase in the specific indexes of competitive activity resulted in a statistically reliable increase of the integral assessment by $11.1 \%(p=0.01)$. It is worth noting that we regarded the overall assessment as the most important index of competitive activity in football players.

\section{Discussion}

Based on the generalization of outcomes of previous studies (Gerhard, 2009; Chtara et al., 2017; Kostiukevych, Lazarenko, Shchepotina, Poseletska et al., 2019), it should be noted that modern tendencies of the development of team sports allow for the viability and efficiency of use of programming for the purpose of optimization of athletes' training. In contrast to the traditional planning, targeted fulfilment of managerial influences is carried out by way of creation of targeted programmes of structural arrangements of the training process in football players. And, above all, regulation of load components is exceptionally important for the formation of training effects (Platonov, 2013; Kostiukevych, Lazarenko, Shchepotina, Kulchytska et al., 2019). Our study substantiates theoretical and methodical foundation for pro-

Table 1. Volume and ratios of training loads in microcycles of the competition period of the second cycle of annual training in skilled football players at the phase of the formation experiment

\begin{tabular}{|c|c|c|c|c|c|c|}
\hline \multirow[b]{2}{*}{ Microcycles } & \multicolumn{5}{|c|}{ Load volume, min } & \multirow{2}{*}{$\begin{array}{l}\text { LVC, points } \\
\quad / \mathrm{CI}_{\mathrm{t}} \text {, } \\
\text { points } \cdot \mathrm{min}^{-1}\end{array}$} \\
\hline & Aerobic & Mixed & $\begin{array}{l}\text { Anaerobic } \\
\text { alactate }\end{array}$ & $\begin{array}{l}\text { Anaerobic } \\
\text { glycolytic }\end{array}$ & Total & \\
\hline $\begin{array}{l}\text { 7-Day competitive } \\
\text { (Recovery and developing) }\end{array}$ & 308 & 246 & 24 & 24 & 602 & $4296 / 7.1$ \\
\hline $\begin{array}{l}\text { 6-Day competitive } \\
\text { (Recovery and developing) }\end{array}$ & 310 & 244 & 32 & 16 & 602 & $4695 / 7.8$ \\
\hline $\begin{array}{l}\text { 5-Day competitive } \\
\text { (developing) }\end{array}$ & 232 & 216 & 28 & 12 & 488 & $3562 / 7.3$ \\
\hline $\begin{array}{l}\text { 4-Day competitive } \\
\text { (developing) }\end{array}$ & 168 & 210 & - & - & 378 & $2722 / 7.2$ \\
\hline 3-Day competitive and recovery & 152 & - & - & - & - & $668 / 4.4$ \\
\hline
\end{tabular}

Notes: $\mathrm{LVC}$ is a load value coefficient; $\mathrm{CI}_{\mathrm{tl}}$ is a coefficient of training load intensity 
Table 2. Comparison of indexes of physical and functional preparedness and competitive activity in skilled football players $(n=18)$ during the competition period of the second cycle of annual training at the phase of the ascertaining and formation experiments

\begin{tabular}{|c|c|c|c|c|c|c|c|}
\hline \multirow{3}{*}{ Name of the test } & \multicolumn{7}{|c|}{ Statistic indices } \\
\hline & \multicolumn{2}{|c|}{ Ascertaining phase } & \multicolumn{2}{|c|}{ Formation phase } & \multirow{2}{*}{$\Delta \mathrm{M}(\%)$} & \multirow{2}{*}{$\mathbf{t}$} & \multirow{2}{*}{$\mathbf{p}$} \\
\hline & $\mathbf{M}$ & SD & $\mathbf{M}$ & SD & & & \\
\hline \multicolumn{8}{|c|}{ Physical preparedness } \\
\hline $30 \mathrm{~m}$ run from high start, $\mathrm{s}$ & 4.35 & 0.26 & 4.29 & 0.23 & $\begin{array}{l}-0.06 \\
(-1.4)\end{array}$ & 0.78 & 0.45 \\
\hline $\begin{array}{l}\text { Long jump from } \\
\text { the spot, } m\end{array}$ & 2.51 & 0.22 & 2.54 & 0.19 & $0.03(1.2)$ & 0.50 & 0.62 \\
\hline $7 \times 50 \mathrm{~m}$ shuttle run, $\mathrm{s}$ & 65.05 & 1.90 & 63.64 & 1.49 & $\begin{array}{l}-1.41 \\
(-2.2)\end{array}$ & $2.09^{\star}$ & 0.05 \\
\hline Cooper test, m & 3082.01 & 176.31 & 3120.23 & 171.14 & $38.22(1.2)$ & 0.73 & 0.48 \\
\hline \multicolumn{8}{|c|}{ Functional preparedness } \\
\hline $\mathrm{PWC}_{170(\mathrm{~V})}, \mathrm{m} \cdot \mathrm{s}^{-1}$ & 3.89 & 0.22 & 4.15 & 0.19 & $0.26(6.7)$ & $3.70^{\star *}$ & 0.00 \\
\hline $\mathrm{PWC}_{170}, \mathrm{kgm} \cdot \mathrm{min}^{-1} \cdot \mathrm{kg}^{-1}$ & 21.60 & 2.79 & 23.10 & 2.18 & $\begin{array}{l}1.60 \\
(6.9)\end{array}$ & $2.13^{*}$ & 0.05 \\
\hline $\mathrm{VO}_{2 \max (\mathrm{rel})}, \mathrm{ml} \cdot \mathrm{min}^{-1} \cdot \mathrm{kg}^{-1}$ & 53.71 & 3.62 & 56.81 & 3.26 & $3.10(5.8)$ & $2.24^{*}$ & 0.04 \\
\hline Overall adaptation index, relative units & 4351.14 & 768.50 & 4114.23 & 713.52 & $\begin{array}{c}-236.91 \\
(-5.4) \\
\end{array}$ & 1.50 & 0.15 \\
\hline \multicolumn{8}{|c|}{ Competitive activity } \\
\hline Intensity coefficient, relative units & 0.78 & 0.11 & 0.89 & 0.11 & $0.11(14.1)$ & $2.75^{\star *}$ & 0.01 \\
\hline Mobility coefficient, relative units & 1.39 & 0.17 & 1.59 & 0.16 & $0.20(14.4)$ & $4.44^{* *}$ & 0.00 \\
\hline Aggressiveness coefficient, relative units & 0.80 & 0.10 & 0.85 & 0.12 & $0.05(6.3)$ & 1.25 & 0.23 \\
\hline Efficiency coefficient, relative units & 0.69 & 0.04 & 0.77 & 0.04 & $0.08(11.6)$ & $5.71^{\star *}$ & 0.00 \\
\hline $\begin{array}{l}\text { Single combat efficiency coefficient, } \\
\text { relative units }\end{array}$ & 0.56 & 0.04 & 0.58 & 0.04 & $0.02(3.6)$ & 1.42 & 0.17 \\
\hline Creativity coefficient, relative units & 0.21 & 0.05 & 0.26 & 0.05 & $0.05(23.8)$ & $2.77^{\star *}$ & 0.01 \\
\hline Integral assessment, relative units & 4.43 & 0.46 & 4.92 & 0.46 & $0.49(11.1)$ & $3.06^{* *}$ & 0.01 \\
\hline
\end{tabular}

Notes: ${ }^{*}$ - the difference in the results is statistically reliable at the level of $\mathrm{p}<0.05$; ${ }^{* *}$ - the difference in the results is statistically reliable at the level of $\mathrm{p}<0.01 ; \mathrm{M}-$ mean; SD - standard deviation

gramming structural arrangements of the training process in skilled football players during the competition period. Practical fulfilment of the proposed approach as well as its experimentally substantiated efficiency are reflected in the process of preparation of the studied football team "Burevisnyk".

During the period of stabilization of the sports form the outcomes are increased, however within the limits of capabilities allowed for by the regularities of maintenance of the current sports form (Matveev, 2010; Platonov, 2013; Kostiukevych, Lazarenko, Shchepotina, Kulchytska et al., 2019). During the competition period a positive tendency of indexes of physical and functional preparedness in football players was evident. It contributed to a more efficient participation of football players in the competitive activity as specific peculiarities of the football game allow for a high level of demonstration of specifically speed qualities, speed and strength qualities and, first of all, speed endurance which corresponds to the player's movement during a match which resembles the shuttle run.

Reliability of use of integral assessment as an objective and informative criterion of effectiveness of competitive activity in skilled football players has been confirmed. Analysis of technical and tactical activity of players based only on quantitative and qualitative indexes is not always objective and sufficiently efficient for managerial influences (Solovey, Mitova, Solovey et al., 2020; Kostiukevych, Shchepotina, \& Vozniuk, 2020). Integral assessment is based on comprehen- sive accounting of technical and tactical activity of football players as it takes into account the coordination complexity of the fulfilment of technical and tactical actions, their tactical meaning, roles of players etc. (Kostiukevych, Imas, Borysova et al., 2018). The improvement of specific indexes of integral assessment of competitive activity of the studied football team clearly shows, on the one side, an increase in the technical and tactical skills of players and, on the other hand, a change in the tactics of the game of the team with an orientation toward a more aggressive tactical model of the game.

We have supplemented the results of the study by Oliveira, Brito, Martins et al (2019) with respect to such parameters of the training process in football players during the competition period as load volume and directly run work with the data on the volume and ratio of means and types of preparation, quantitative indexes of training sessions of different pedagogical orientation. The data on the control of indexes of physical (Godik, 2006; Karsten, Larumbe-Zabala, Kandemir et al., 2016) and functional preparedness (Shamardin, 2013; Slimani, Znazen, Miarka et al., 2019) and competitive activity (Kostiukevych, Imas, Borysova et al., 2018; Kostiukevych, Shchepotina, \& Vozniuk, 2020) in skilled football players were further developed. Besides, the obtained data on the volume and ratio of training loads of various orientation in skilled football players of the student team supplement and expand the outcomes of the study by Shamardin (2013) on elite football players. 
Analysis of the obtained results confirms the reliability of the use of the represented programme of the competition period in the practice of preparation of student teams as well as skilled football players. Besides, the described scientific and methodical method was approved in the process of organizing the training process of the skilled female volleyball players during the preparatory period (Kostiukevych, Shchepotina, Shynkaruk et al., 2019). It confirms the feasibility of use of the programming method for practical preparation of team sports athletes in the annual macrocycle. Among the promising directions we see the study of the problem of programming of the training process of athletes at the phases of long-term improvement which is substantiated by the need to create longterm programmes for preparation of the skilled sports reserve.

\section{Conclusions}

1. Programming is a new, more progressive form of planning of the training process which allows more reliably to accomplish the targeted outcome depending on the comprehensive influence of various factors. Theoretical and methodical aspects of programming of the training process may be conditioned upon the hierarchical structure, in which smaller programmatic structural arrangements are subordinate to the larger ones; the objectives with respect to the training programmes at every phase of the training macrocycle; general and special principles of athlete training; algorithmicity, i.e. step-by-step planning and correction of managerial influences; proper selection of training means and use of training loads with different focuses in the process of training cycles; use of informational criteria for control at every phase of the training process.

2. The developed programme of the competition period in skilled football players consisted of four blocks which determined the types and ratios of training work, quantitative indexes of training sessions and games, ratios of means and training loads as well as preparedness criteria. The proposed programme of the competition period was fulfilled through the programmes of macrocycles in which load components were clearly regulated for the purpose of forming training effects.

3 . The effectiveness of organization of structural arrangements of the training process of skilled football players over the competition period on the basis of programming is confirmed by a statistically reliable improvement of indexes of physical and functional preparedness and competitive activity in players in the range from 2.2 to $23.8 \%$.

\section{Acknowledgements}

The research was carried out within the framework of the plan of the research work of the Department of Theory and Methodology of Sports of Vinnytsia Mykhailo Kotsiubynskyi State Pedagogical University for 2016-2020 «Theoretical and Methodological Foundations of Programming and Modeling of the Training Process of Sportsmen of Different Qualifications» (state registration number 0116U005299) and for 2021-2025 «Organizational and methodological principles of programming the training process of gratified and highly gratified athletes» (state registration number 0121U109550).

\section{Conflict of interests}

The authors state that there is no conflict of interests.

\section{References}

Kostiukevych, V., Lazarenko, N., Shchepotina, N., Kulchytska, I., Svirshchuk, N., Vozniuk, T., Kolomiets, A., Konnova, M., Asauliuk, I., Bekas, O., Romanenko, V., \& Hudyma, S. (2019). Management of athletic form in athletes practicing game sports over the course of training macrocycle. Journal of Physical Education and Sport, 19(Supplement issue 1), 28-34. https://doi.org/10.7752/jpes.2019.s1005

Andrade, D. M., Fernandes, G., Miranda, R., Reis Coimbra, D., \& Bara Filho, M. G. (2021). Training Load and Recovery in Volleyball During a Competitive Season. The Journal of Strength \& Conditioning Research, 35(4), 1082-1088. https://www.doi.org/10.1519/JSC.0000000000002837

Duarte, T. S., Coimbra, D. R., Miranda, R., Toledo, H. C., Werneck, F. Z., Freitas, D. G. S. D., \& Bara Filho, M. G. (2019). Monitoring training load and recovery in volleyball players during a season. Revista Brasileira de Medicina do Esporte, 25(3), 226-229. https://doi.org/10.1590/1517-869220192503195048

Oliveira, R., Brito, J. P., Martins, A., Mendes, B., Marinho, D. A., Ferraz, R., \& Marques, M. C. (2019). In-season internal and external training load quantification of an elite European soccer team. PloS one, 14(4). https://doi.org/10.1371/journal.pone.0209393

Manzi, V., D’ottavio, S., Impellizzeri, F. M., Chaouachi, A., Chamari, K., \& Castagna, C. (2010). Profile of weekly training load in elite male professional basketball players. The Journal of Strength \& Conditioning Research, 24(5), 1399-1406. https://www.doi.org/10.1519/JSC.0b013e3181d7552a

Kostiukevych, V., Lazarenko, N., Shchepotina, N., Poseletska, K., Stasiuk, V., Shynkaruk, O., Borysova, O., Denysova, L., Potop, V., Vozniuk, T., Dmytrenko, S., Kulchytska, I., Konnova, M., \& Iakovenko, O. (2019). Programming of the training process of qualified football players in the competitive period of the macrocycle. Journal of Physical Education and Sport, 19(Supplement issue 6), 2192-2199. https://www.doi.org/10.7752/jpes.2019.s6329

Bompa, T. O., \& Haff, G. G. (2009). Periodization: Theory and Methodology of Training. Champaign, IL, USA: Human Kinetics.

Platonov, V.N. (2013). Periodizaciia sportivnoj trenirovki. Obshchaia teoriia i ee prakticheskoe primenenie. Kyiv: Olympic Literature. (in Russian)

Koryahin, V., Blavt, O., Doroshenko, E., Prystynskyi, V., \& Stadnyk, V. (2020). Training Effect of Special Basketball Exercises. Teoriâ ta Metodika Fizičnogo Vihovannâ, 20(3), 137-141. https://doi.org/10.17309/tmfv.2020.3.02

Kostiukevich, V.M., Stasiuk, V.A., Shchepotina, N.Yu., \& Dyachenko, A.A. (2017). Programming of skilled football players training process in the second cycle of specially created training during the year. Physical Education of Students, 21(6), 262-269.

https://doi.org/10.15561/20755279.2017.0602

Gerhard, F. (2009). Soccer Training Programs. 2nd Ed. UK: Meyer \& Meyer Verlag.

Khudolii, O. (2019). Research Program: Modeling of Young Gymnasts' Training Process. Teoriâ ta Metodika Fizičnogo Vihovannâ, 19(4), 168-178. https://doi.org/10.17309/tmfv.2019.4.02

Adamchuk, V. V. (2020). Programming of training classes of highly qualified ten-fighter athletics at the stage of direct for competition. Fizychna kultura, sport ta zdorovya 
natsiyi, 9(28), 98-105.

https://doi.org/10.31652/2071-5285-2020-9(28)-98-105 (in Ukrainian)

Malikova, A.N., Doroshenko, E.Yu., Symonik, A.V., Tsarenko, E.V., \& Veritov, A.I. (2018). The ways of improvement special physical training of high-qualified women volleyball players in competitive period of annual macrocycle. Physical Education of Students, 22(1), 38-44. https://doi.org/10.15561/20755279.2018.0106

Veličković, M., Bojić, I., \& Berić, D. (2018). The Effects Of Programmed Training On Development Of Explosive Strength In Female Volleyball Players. Facta Universitatis, Series: Physical Education and Sport, 15(3), 493-499. https://doi.org/10.22190/FUPES1703493V

Karsten, B., Larumbe-Zabala, E., Kandemir, G., Hazir, T., Klose, A., \& Naclerio, F. (2016). The effects of a 6-week strength training on critical velocity, anaerobic running distance, 30-M sprint and Yo-Yo intermittent running test performances in male soccer players. PloS one, 11(3). https://doi.org/10.1371/journal.pone.0151448

Chtara, M., Rouissi, M., Haddad, M., Chtara, H., Chaalali, A., Owen, A., \& Chamari, K. (2017). Specific physical trainability in elite young soccer players: efficiency over 6 weeks' in-season training. Biology of sport, 34(2), 137-148. https://doi.org/10.5114/biolsport.2017.64587

Shamardin, V.M. (2013). Tekhnologiia upravlinnia sistemoiu bagatorichnoi pidgotovki futbol'nikh komand vishchoi kvalifikacii. Dokt. Dis. Lviv. (in Ukrainian)

Godik, M.A. (2006). Fizicheskaya podgotovka futbolistov. Moscow: Terra-Sport, Olimpia Press. (in Russian)

Kostiukevich, V.M. (2016). Upravleniye trenirovochnym protsessom futbolistov $v$ godichnom tsikle podgotovki: monografiya. Kyiv: KNT. (in Russian)

Johnson, R., Haskvitz, E., \& Brehn, B. (2009). Applied sports medicine for coaches. Baltimore Wolters Kluwer / Lippcott Williams and Williams.

Wilmore, I.H., Costill, D.L., \& Kenney, L.W. (2012). Physiology of sport and exercise. Illinois: Human Kinetics.

Karpman, V.M., Belotserkovskiy, Z.B., \& Gudkov, I.L. (1988). Testirovaniye v sportivnoy meditsine. Moscow: Physical Culture and Sport. (in Russian)
Kostiukevych, V., Imas, Ye., Borysova, O., Dutchak, M., Shynkaruk, O., Kogut, I., Voronova, V., Shlonska, O., \& Stasiuk, I. (2018). Modeling of the athletic training process in team sports during an annual macrocycle. Journal of Physical Education and Sport, 18(1), 327-334. https://doi.org/10.7752/jpes.2018.s144

Kostiukevych, V., Shchepotina, N., \& Vozniuk, T. (2020). Monitoring and Analyzing of the Attacks of the Football Team. Teoriâ ta Metodika Fizičnogo Vihovannâ, 20(2), 6876. https://doi.org/10.17309/tmfv.2020.2.02

Matveev, L. P. (2010). Obshchaya teoriya sporta i yeye prikladnyye aspekty; 5-ye izd. Moscow: Sov. sport. (in Russian)

Byshevets, N., Shynkaruk, O., Stepanenko, O., Gerasymenko, S. Tkachenko, S., Synihovets, I., Filipov, V., Serhiyenko, K, \& Iakovenko, O. (2019). Development skills implementation of analysis of variance at sport-pedagogical and biomedical researches. Journal of Physical Education and Sport, 19(6), 2086-2090. https://doi.org/10.7752/jpes.2019.s6311

Solovey, O. M., Mitova, O., Solovey, D., Boguslavskyi, V., \& Ivchenko, O. (2020). Analysis and generalization of competitive activity results of handball clubs in the game development aspect. Pedagogy of Physical Culture and Sports, 24(1), 36-43. https://doi.org/10.15561/26649837.2020.0106

Slimani, M., Znazen, H., Miarka, B., \& Bragazzi, N. L. (2019). Maximum Oxygen Uptake of Male Soccer Players According to their Competitive Level, Playing Position and Age Group: Implication from a Network MetaAnalysis. Journal of human kinetics, 66(1), 233-245. https://doi.org/10.2478/hukin-2018-0060

Kostiukevych, V., Shchepotina, N., Shynkaruk, O., Kulchytska, I., Borysova, O., Dutchak, M., Vozniuk, T., Yakovliv, V., Denysova, L., Konnova, M., Khurtenko, O., Perepelytsia, O., Polishchuk, V., \& Shevchyk, L. (2019). Training process construction of the qualified volleyball women players in the preparatory period of two-cycle system of the annual training on the basis of model training tasks. Journal of Physical Education and Sport, 19(Supplement issue 2), 427-435. https://doi.org/10.7752/jpes.2019.s2063

\section{УПРАВЛІННЯ ТРЕНУВАЛЬНИМ ПРОЦЕСОМ СПОРТСМЕНІВ КОМАНДНИХ ІГРОВИХ ВИДІВ СПОРТУ В ЗМАГАЛЬНОМУ ПЕРІОДІ НА ОСНОВІ ПРОГРАМУВАННЯ (НА МАТЕРІАЛІ ФУТБОЛУ)}

\section{Наталя Щепотіна ${ }^{1 \mathrm{ABCDE}}$, Віктор Костюкевич ${ }^{1 \mathrm{ABCDE}}$, Інна Асаулюк ${ }^{1 B C D E}$, Вадим Стасюк $^{2 B C D E}$, Тетяна Вознюк ${ }^{1 \mathrm{BCDE}}$, Світлана Дмитренко ${ }^{1 \mathrm{BCDE}}$, Вадим Адамчук ${ }^{18 C D E}$}

${ }^{1}$ Вінницький державний педагогічний університет імені Михайла Коцюбинського

${ }^{2}$ Кам’янець-Подільський національний університет імені Івана Огієнка

Авторський вклад: А - дизайн дослідження; В - збір даних; C - статаналіз; D - підготовка рукопису; Е - збір коштів

Реферат. Стаття: 6 с., 2 табл., 4 рис., 31 джерело.

Мета дослідження - експериментально обгрунтувати ефективність побудови структурних утворень тренувального процесу кваліфікованих футболістів у межах змагального періоду на основі програмування.
Матеріал і методи. У дослідженні взяли участь 18 кваліфікованих футболістів студентської команди «Буревісник». Середній вік досліджуваних становив 19,8 \pm 5,8 років, кваліфікація - I розряд. Програма змагального пе- 
ріоду кваліфікованих футболістів складалася з чотирьох блоків: у першому з них представлені види та співвідношення тренувальної роботи, в другому - кількісні показники тренувальних занять (неспецифічних, специфічних, комплексних) та ігор (навчальних, контрольних, офіційних), у третьому - співвідношення засобів (загальнопідготовчих, спеціально-підготовчих, підвідних, змагальних) i тренувальних навантажень (аеробних, змішаних аеробноанаеробних, анаеробних алактатних, анаеробних гліколітичних), у четвертому - критерії підготовленості.

Результати. Було здійснено перерозподіл тренувальних навантажень різної спрямованості з урахуванням специфіки змагальних навантажень кваліфікованих футболістів. Так, частки навантажень аеробної й анаеробної гліколітичної спрямованості на формувальному етапі експерименту були збільшені до 53,6 і 3,0\% відповідно, а навантажень змішаної й анаеробної алактатної спрямованості - зменшені до 40,0 і 3,4\% відповідно. Спостерігалася позитивна динаміка показників фізичної $(1,2-2,2 \%)$ і функціональної
(5,4-6,7\%) підготовленості та змагальної діяльності (3,6$23,8 \%)$ кваліфікованих футболістів на етапі формувального експерименту, в порівнянні з констатувальним.

Висновки. Теоретико-методичні аспекти програмування тренувального процесу мають бути обумовлені: ієрархічною структурою, в якій менші програмні структурні утворення підпорядковані більшим; цільовими установками щодо програм підготовки на кожному з етапів тренувального макроциклу; загальними та спеціальними принципами підготовки спортсменів; алгоритмічністю - покроковим плануванням і корекцією управлінських впливів; адекватним підбором тренувальних засобів і використанням тренувальних навантажень різної спрямованості в процесі тренувальних циклів; використанням інформативних критеріїв контролю на кожному з етапів тренувального процесу.

Ключові слова: футболісти, змагальний період, програма, управлінські впливи, мікроцикли, спрямованість навантаження, величина навантаження, фізична підготовленість, функціональна підготовленість, змагальна діяльність.

\section{Information about the authors:}

Shchepotina N.Yu.: shchepa@mbox.vn.ua; http://orcid.org/0000-0002-9507-3944; Department of Theory and Methodology of Sports, Vinnytsia Mykhailo Kotsiubynskyi State Pedagogical University, Ostrozhskyi St, 32, Vinnytsia, 21100, Ukraine.

Kostiukevych V.M.: kostykevich.vik@gmail.com; http://orcid.org/0000-0002-6215-764X; Department of Theory and Methodology of Sports, Vinnytsia Mykhailo Kotsiubynskyi State Pedagogical University, Ostrozhskyi St, 32, Vinnytsia, 21100, Ukraine.

Asauliuk I.O.: innaasauliuk@gmail.com; http://orcid.org/0000-0001-8119-2726; Department of Theory and Methodology of Physical Education, Vinnytsia Mykhailo Kotsiubynskyi State Pedagogical University, Ostrozhskyi St, 32, Vinnytsia, 21100 , Ukraine.

Stasiuk V.A.: stasyukva@ukr.net; https://orcid.org/0000-0002-7512-5794; Department of Sports and Sports Games, KamianetsPodilskyi Ivan Ohiienko National University, Ohiienko St, 61, Kamianets-Podilskyi, Khmelnytsky reg, 32301, Ukraine.

Vozniuk T.V.: TV_Vinnitsa@ukr.net; http://orcid.org/0000-0002-5951-7333; Department of Theory and Methodology of Sports, Vinnytsia Mykhailo Kotsiubynskyi State Pedagogical University, Ostrozhskyi St, 32, Vinnytsia, 21100, Ukraine.

Dmytrenko S.M.: sdmitrenko73@gmail.com; http://orcid.org/0000-0001-5934-4893; Department of Theory and Methodology of Physical Education, Vinnytsia Mykhailo Kotsiubynskyi State Pedagogical University, Ostrozhskyi St, 32, Vinnytsia, 21100, Ukraine. Adamchuk V.V.: vadim-adamchuk@ukr.net; http://orcid.org/0000-0002-5009-7221; Department of Theory and Methodology of Sports, Vinnytsia Mykhailo Kotsiubynskyi State Pedagogical University, Ostrozhskyi St, 32, Vinnytsia, 21100, Ukraine.

Cite this article as: Shchepotina, N., Kostiukevych, V., Asauliuk, I., Stasiuk, V., Vozniuk, T., Dmytrenko, S., \& Adamchuk, V. (2021). Management of Training Process of Team Sports Athletes During the Competition Period on the Basis of Programming (Football-Based). Teoriâ ta Metodika Fizičnogo Vihovannâ, 21(2), 142-151. https://doi.org/10.17309/tmfv.2021.2.07

Received: 13.04.2021. Accepted: 18.05.2021. Published: 25.06.2021

This work is licensed under a Creative Commons Attribution 4.0 International License (http://creativecommons.org/licenses/by/4.0). 